\title{
The Transformation of Islamic Art during the Sunni Revival
}

Yasser Tabbaa

Seattle and London: University of Washington Press, 2001. 210 pages.

The Islamic world underwent profound political and religious changes in the eleventh and twelfth centuries. These changes were paralleled by one of the most significant transformations of Islamic art and architecture. What shared 
meaning lies at the origins of these two historical developments? How, if at all, were these paralleled transformations part of the same struggle?

The Transformation of Islamic Art during the Sunni Revival takes us into this dialogue. This work consists of seven chapters, including a plethora of beautiful photographs, in which Yasser Tabbaa, a professor at the University of Michigan and a highly regarded Islamic art scholar, argues that the transformations in medieval Islamic architecture and ornament during this period reflected and embodied the conflict between the "Abbasid and Fatimid dynasties. It is in the struggle for political authority and religious legitimacy that new and competing forms of expression took hold.

In discussing the book's themes and the discourses of which it is a part, Tabbaa refutes the essentialist traditions of some Orientalists, art historians, and even aestheticians that, while having seemingly different intentions, all portray Islamic art as separate or divorced from its history. They ignore or gloss over significant historical developments in the Islamic world, and therefore represent Islamic art, in all of its variety, as a homogenous genre, as the term arabesque implies. Tabbaa highlights the epoch of the Sunni revival by rejecting the essentialist models and focusing on the period's unique conflicts and changes. He argues that calligraphic, ornamental, and architectural forms, in addition to being instruments of perceptual mediation, were engendered within specific discourses to give symbolic support to certain claims to authority and to establish a difference against challenging claims.

The conflict between the "Abbasid and Fatimid dynasties during this period was not based upon power alone, but upon differing religious ideologies and worldviews. In his first chapter, "The Sunni Revival," Tabbaa introduces his readers to the development of this conflict's various characteristics. The Mu'tazilah's unique perspective of God and the Qur'an was embraced by the early 'Abbasid caliphate and other Shi' $i$ groups. Yet the growing popularity of Ash 'ari thought and the canonization of the "unity" of the four madhhabs led the "Abbasid caliphate defensively to distance itself from $\mathrm{Mu}$ 'tazili reasoning and specifically from Isma'ili Shi'ism. Such developments led to a growing gap between 'Abbasid and Shi'i ideology, and directed emphasis to the preexisting question of legitimate political and religious authority.

As Shi'ism grew in prevalence and the Isma'ili Fatimids grew in strength, having conquered central North Africa and Sicily, 'Abbasid authority was seriously threatened and under increasing pressure to legitimate its rule and consolidate its power. In chapter 2, "The Transformation of Qur'anic Writing," Tabbaa clearly shows a connection between the 
'Abbasid's perceived goals in the midst of this threat and the development of Islamic calligraphy in the historical figure of Ibn Muqla, the calligrapher responsible for the system of proportion that allowed systematic templates to be produced for the six major scripts. Yet he was also the vizier of three consecutive Abbasid caliphs, including al-Muqtadir, during whose reign he produced a canonical recension of the Qur'an based on his calligraphical model. Furthermore, the 'Abbasid state empowered members of the administration, including Ibn Muqla, to punish scholars whose views or readings of the Qur'an diverged from the newly canonized version. Thus the 'Abbasids, as Tabbaa explains, directly supported the development of calligraphical expression in Qur'anic writing and also in monumental inscriptions, as described in chapter 3 , in order to redefine and claim ownership over a renewed essence of Islam.

Art, like culture and religion, expresses and defines itself and is then remembered in terms of what it is not, in terms of that from which it seeks to distinguish itself. This theme, articulated clearly in the introduction, is one of Tabbaa's supportive arguments and is revisited by each chapter. While each of the art forms discussed spread rapidly throughout Iran, Iraq, Syria, and North Africa during this period, they are not found at all in Cairo until the end of the Fatimid dynasty (1171). The symbolism expressed in these renewed art forms was not intended to appeal to, nor was it absorbed by, the Fatimids, whose ideology of political and religious legitimacy differed greatly from that of the "Abbasids. As Tabbaa discusses this point in great detail, it becomes clear that the symbolism utilized in these art forms was specifically engendered to reflect aspects of orthodox Islam as understood by the 'Abbasids, and to distinguish itself from competing perspectives, particularly those of the Fatimids.

The art forms discussed in chapters 4-6 are some of the most popular ornamental and architectural forms known as having Arabo-Islamic origins. Tabbaa discusses the development of vegetal and geometric arabesque ornament, muqarnas (honeycomb vaulting), muqarnas domes, and other special architectural devices dated to the eleventh and twelfth centuries of the 'Abbasid kingdom with the same comprehensiveness displayed in his analysis of the development of Islamic calligraphy. Rejecting essentialist models, he addresses how each art form was engendered with specific meanings throughout the transformations leading up to and during the 'Abbasid dynasty. Each art form then underwent unique transformations in form and symbolic meaning that were directly related to 'Abbasid policies during the Sunni revival. 
The Transformation of Art during the Sunni Revival provides a detailed description of calligraphical, ornamental, and architectural developments during this period. It also establishes concrete links between the transformations in form and meaning experienced by these art forms and the contemporaneous political and religious rivalries. This work is clearly of great value to art history, in that it explores in depth how artistic form and symbolism reflect the unique aspects of a culture, social structure, and time period. Yet it is also a significant contribution to Islamic history, for it challenges scholars of Islam and the Middle East to realize that a better understanding of Islamic history lies "in problematizing instead of glossing over ruptures, disjunctions, and discontinuities."

Daniel Micallef, Graduate Student Center for Middle East Studies University of Texas in Austin Austin, Texas 